\title{
COLUMBIA RIVER HYDROGRAPH
}

By

R. T. Jaske

Research Associate

Earth Sclences Section

Environmental and Radiological Sciences Department

June 15,1967

NOTICE

This report was prepared as an account of work This report was prepared States Government. Neither sponsored by the Unt the United States Atomic Energy the United star any of their employees, nor any of Commission, their contractors, subcess or implied, or assumes any makes any warrantity for the accuracy, com legal liability or runess of any information, opparatus, pleteness or usefuls

would not infringe privately owned rights.

\section{INFORMATION CONCERNING USE OF THIS REPORT}

\section{PATENT STATUS}

This document copy, since it is transmitted in advance of potent cleoronce, is mode croilable in confidence solely for use in performance of work under controcts with the U. S. Alomic Energy Commission. This document is not to be published nor its contents otherwise disseminoted or used for purposes other than specified above before potent approvol for such release or uss has been secured, upon request, from the Chiof, Chicago Patent Group, U. S. Atomic Energy Commission. 9800 So. Coss Ave., Argonne, illinois.

\section{PRELIMINARY REYORT}

This report contains information of o preliminary noture prepaced in the course of wark under Alomic Energy Commission Contract AT(45-1)-1830. This information is subject to correction or modifico tion upon the collection and evaluation of additional dafa.

\section{LEC.AL NOTICE}

This report was prepared as on account of Government sponsored work. Neither the United Stotes. nor the Commission, nor ony person acting on behalf of the Commission:

A. Makes any warronty or representation, expressed or implied, with respect to the accuracy, completeness, or usefulness of the information contained in this report, or that the use of any information. apporalus, method, or process disclosed in this report moy not infringe privalely owned rights; or

B. Assumes ony liabilities with respect to the use of, or for damages resulting from the use of any information, opparafus, method, or process disclosed in this report.

As used in the above, "person acting on behalf of the Commission includes any employee or contractor of the Commission, or employee of such controctor, to the extent that such employee or con tractor of the Commissios, or employee of such contractor prepores, disseminates, or provides access 10 , any information pursuant to his employment or controct with the Commission, or his employment with
sueh controctor.

\section{PACIFIC NORTHWEST LABORATORY}

RICHLAND, WASHINGTON

OPERATEd bY
BATTELLE MEMORIAL INSTRDLFTRIBUTION OF THIS DOCUMENT IS UNLIMI

for the 


\section{DISCLAIMER}

This report was prepared as an account of work sponsored by an agency of the United States Government. Neither the United States Government nor any agency Thereof, nor any of their employees, makes any warranty, express or implied, or assumes any legal liability or responsibility for the accuracy, completeness, or usefulness of any information, apparatus, product, or process disclosed, or represents that its use would not infringe privately owned rights. Reference herein to any specific commercial product, process, or service by trade name, trademark, manufacturer, or otherwise does not necessarily constitute or imply its endorsement, recommendation, or favoring by the United States Government or any agency thereof. The views and opinions of authors expressed herein do not necessarily state or reflect those of the United States Government or any agency thereof. 


\section{DISCLAIMER}

Portions of this document may be illegible in electronic image products. Images are produced from the best available original document. 
COLUMBIA RIVER HYIDROGRAPH

In response to inquiries regarding the potential upper limits of Columbia River water levels, it became apparent that there was no standard reference to which all contractor personnel at the Hanford project could refer. A search for available information revealed some conflicts with old publication materlal. Accordingly, the attached. Hydrograph is presented to the distribution as a proposed official Hydrograph for use in the river reach of interest.

Any comments regarding errors or deletions should be directed to the author in order that appropriate corrections be made before final issue as a planning document.

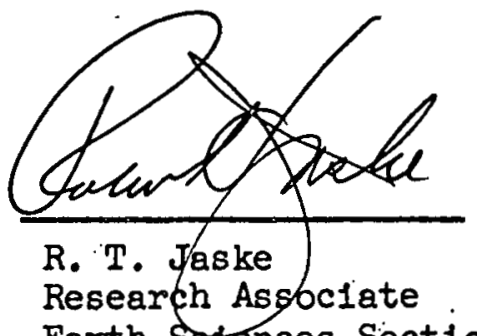

Earth Setences Section

Environmental and Radiological Sciences

Department 
COLUMBIA RIVER HYDROGRAPH

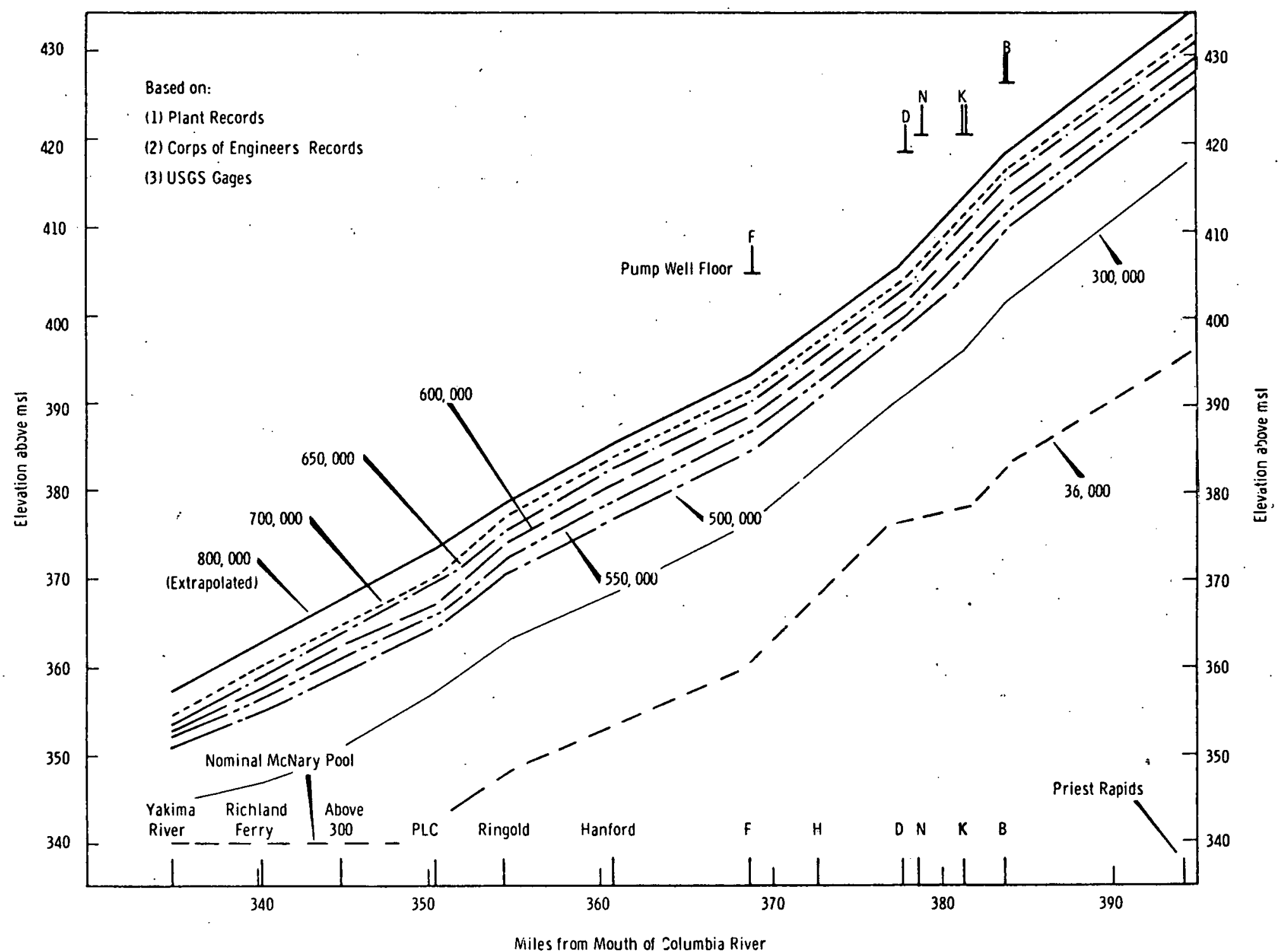

